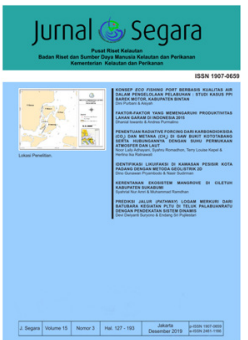

JURNAL SEGARA

http://ejournal-balitbang.kkp.go.id/index.php/segara

ISSN : 1907-0659

e-ISSN : 2461-1166

Nomor Akreditasi: 766/AU3/P2MI-LIPI/10/2016

\title{
ESTIMATION OF SEDIMENT DISTRIBUTION BASED ON BATHYMETRY ALTERATION (2014-2016) IN THE INNER BAY OF AMBON, MALUKU, INDONESIA
}

\section{PERHITUNGAN DISTRIBUSI SEDIMEN BERDASARKAN PERUBAHAN BATIMETRI (2104-2016) DI TELUK AMBON DALAM, MALUKU, INDONESIA}

\author{
Guntur A. Rahmawan, Wisnu A. Gemilang, Ulung J. Wisha, Ruzana Dhiauddin \& Koko Ondara
}

Research Institute of Coastal Resources and Vulnerability, Ministry of Marine Affairs and Fisheries

Jl. Raya Padang-Painan km. 16, Bungus, Padang, Sumatera Barat 25245

Received: 24 May 2018; Revised: 23 January 2019; Accepted: 11 February 2019

\begin{abstract}
The development of Ambon city is centered around Ambon Bay. As the major area of marine and social activities, changes occurred directly affect to seawater degradation. Sedimentation is the main issue that has been occurring. Marine ecosystem can be potentially hampered by the high rate of sedimentation in the Inner Bay of Ambon (TAD). This study aimed to determine the distribution of sediment volume within the bay. Bathymetry of TAD was surveyed using transducer (Echosounder Echo track CVM Teledyne Odom Hydrographic Single Beam), which the depth of certain position was connected to GPS to record all the position data accurately. The field data are then analyzed spatially modelled in the form of 2D and 3D maps, overlaid with the past bathymetry data to calculate the bathymetry alteration and sediment volume estimation during 2014-2016. The depth of TAD in 2014 ranged between 0 - -42 meters, while, in 2016 the water depth slightly changed to $0--44$ meters. The reduction of the water depth is observed in the $25-125 \mathrm{~m}$ from shoreline, where the bed thickness changes observed ranging from $0.1-1.4 \mathrm{~m}$. Total volume of sediment augmentation reaches 13,236,182 $\mathrm{m}^{3}$ that covers about $67.67 \mathrm{Ha}$. Tidal current, that ranged averagely from 0-1.2 m/s, has a tremendous influence on sediment transport in TAD. The bay mouth, that is a semienclosed enclosed area, triggers sediment accumulation due to the weak tidal current transport. If ongoing, these conditions may endanger the environment and biota survival ability.
\end{abstract}

Keywords: Sediment distribution, bathymetry alteration, Inner Bay of Ambon.

\begin{abstract}
ABSTRAK
Teluk Ambon menjadi pusat dari berbagai aktifitas, termasuk aktifitas sosial dan ekonomi kelautan. Perkembangan kota Ambon sebagai pusat kegiatan tersebut, menimbulkan berbagai perubahan yang menyebabkan penurunan kualitas air laut. Penelitian ini bertujuan untuk menghitung distribusi volume sedimentasi yang saat ini sedang menjadi permasalahan utama di Teluk Ambon Dalam (TAD). Pengukuran batimetri dilakukan menggunakan tranduser (Echosounder Echo track CVM Teledyne Odom Hydrographic Single Beam) untuk mengetahui nilai kedalaman, yang terhubung dengan GPS. Hasil pengukuran tersebut dianalisis secara spasial dan dimodelkan menjadi peta $2 D$ dan $3 D$, yang kemudian dibandingkan dengan pengukuran batimetri sebelumnya untuk memperoleh perubahan batimetri dan volume sedimen selama kurun waktu 2014 - 2016. Kedalaman TAD pada tahun 2014 berkisar antara 0 - -42 meter, sedangkan pada tahun 2016 kedalamannya sedikit mengalami perubahan menjadi 0 - -44 meter. Penurunan kedalaman ini diamati pada jarak 25 - 125 meter dari garis pantai, dimana ketebalan sedimen pada posisi tersebut adalah 0,1-1,4 meter. Perhitungan menunjukkan bahwa volume total penambahan sedimen di kawasan TAD mencapai 13.236.182 $\mathrm{m}^{3}$ yang mencakup area seluas 67,67 Ha. Rata-rata kecepatan arus pasang surut sebesar $0-1,2 \mathrm{~m} / \mathrm{d}$ sangat mempengaruhi pergerakan sedimen di lokasi penelitian. Mulut teluk yang semi tertutup memicu akumulasi sedimen karena pergerakan arus pasang surut yang lemah. Jika sedimentasi di wilayah ini terus berlangsung dan tidak ditangani dengan tepat, maka dapat membahayakan keberlangsungan lingkungan serta biota disekitarnya.
\end{abstract}

Kata kunci: Distribusi sedimen, perubahan batimetri, Teluk Ambon Dalam.

Corresponding author:

Jl. Pasir Putih I Ancol Timur, Jakarta Utara 14430. Email: guntura06@gmail.com 


\section{INTRODUCTION}

Ambon Island is part of Maluku Archipelago included into volcanic arc (Pownall et al., 2013). This small island associated with subduction zone that has a high vulnerability toward the natural disasters such as erosion, and slope landslide of the certain condition (Souisa et al., 2016). Nowadays, coastal areas are still developed due to the increasing of human population growth (Wu et al., 2008), which it may evoke many problems during the development process. Local conflicts are undoubtedly avoided related to land utilization complaints and environmental issues (Purwoko, 2009).

Developments of resources utilization in Ambon Bay coastal area are widely applied by stakeholder by which marine transportations, capture fisheries segments, markets, agricultures, mangrove forest conversions, industries, settlement areas, and tourism sites take place. Furthermore, land clearing and building are rapidly exploited. Natural resources usage exceeding the nature balance might cause degradation of coastal area (Kakisina et al., 2015). One of the degradation examples in Ambon Bay is coastal accretion, erosion and declination of its natural resources.

Coastline changing of Ambon Island were mainly affected by erosion and accretion processes (Nova et al., 2016). Land clearing in the hill area utilized as settlements, offices complex and a level $\mathrm{C}$ mining sites causes erosion, sedimentation (Kakisina, 2009), pollution, coastline changes, sedimentation, and bay silting (Bappeda Kota Ambon, 2009).
Sedimentation, one of the problems occurred in the TAD (Teluk Ambon Dalam or Ambon Bay), is instigated by land clearing without sedimentation effects consideration (Tuhumury et al., 2007). This issue become a necessary examination in the last few decades, which in 1987 Hamzah found a sedimentation rate of $11.90 \mathrm{~mm} / \mathrm{year}$, while Tuhumurry et al. (2007) estimated sedimentation debit of $27.36 \mathrm{~kg} / \mathrm{sec}$ via Waiyate (Lateri) river. Sedimentation upshot in this area initiating a disruption to the coastal environment (Suyadi, 2017) including seagrass (Irawan \& Nganro, 2016) and coral reef disappearance (Sihasale, 2013).

Bathymetry survey is an important way to understand sedimentation processes in TAD. According to Noya et al. (2017) modelling approach is one of the robust methods to interpret any processes arise in the coastal waters. One of the approaches is bathymetry change modelling, which was used in this study to examine the seabed topography changes to then calculate the sedimentation rate. The sedimentation mechanism can be determined by the tidal current pattern. TAD is semi-enclosed water area where tidal current is predominant, controlling the sedimentation process occurred within the bay.

Several previous related studies conducted in TAD and surrounding have been published. Mizushima et al. (2007) calculated sedimentation rate and analyzed the grain size of sediment in TAD in order to describe the influence of sedimentation mechanism on plankton vertical distribution. Tuhumury et al. (2017) identified the sedimentation problem and conducted the best management of coastal area of Ambon Bay. Therefore, a study regarding sedimentation rate and distribution within TAD is essential because

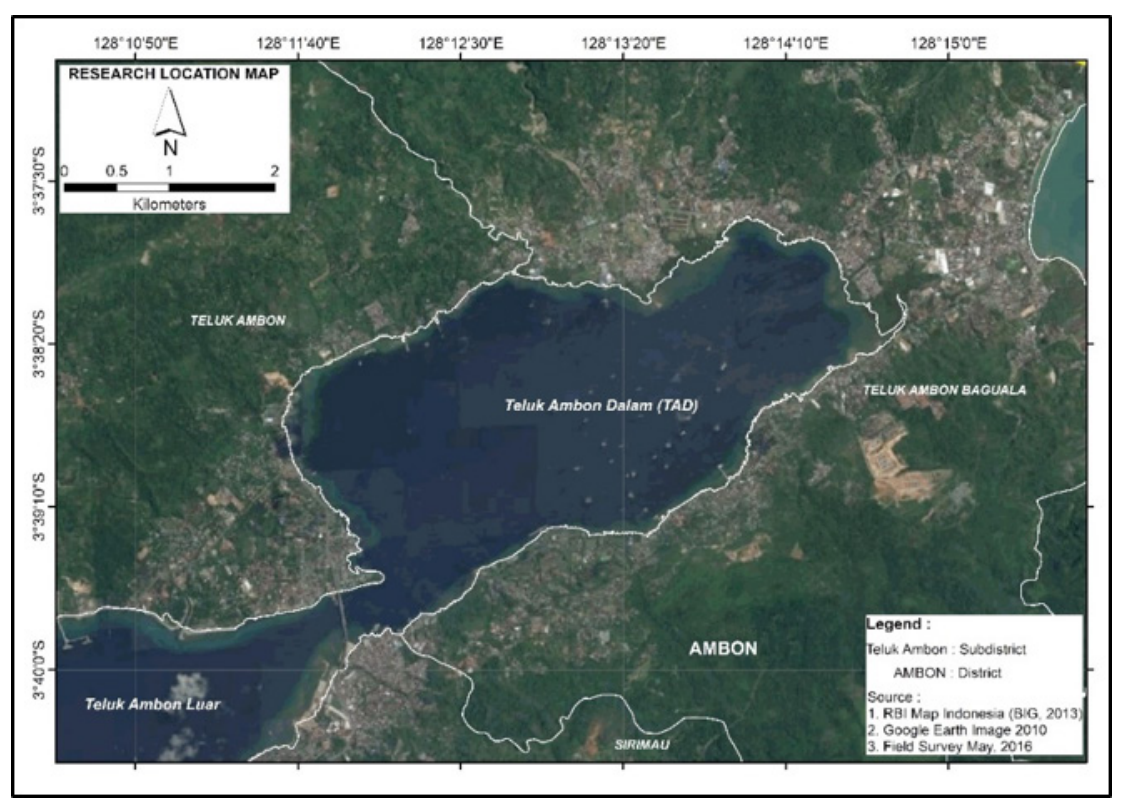

Figure 1. Research location map. 


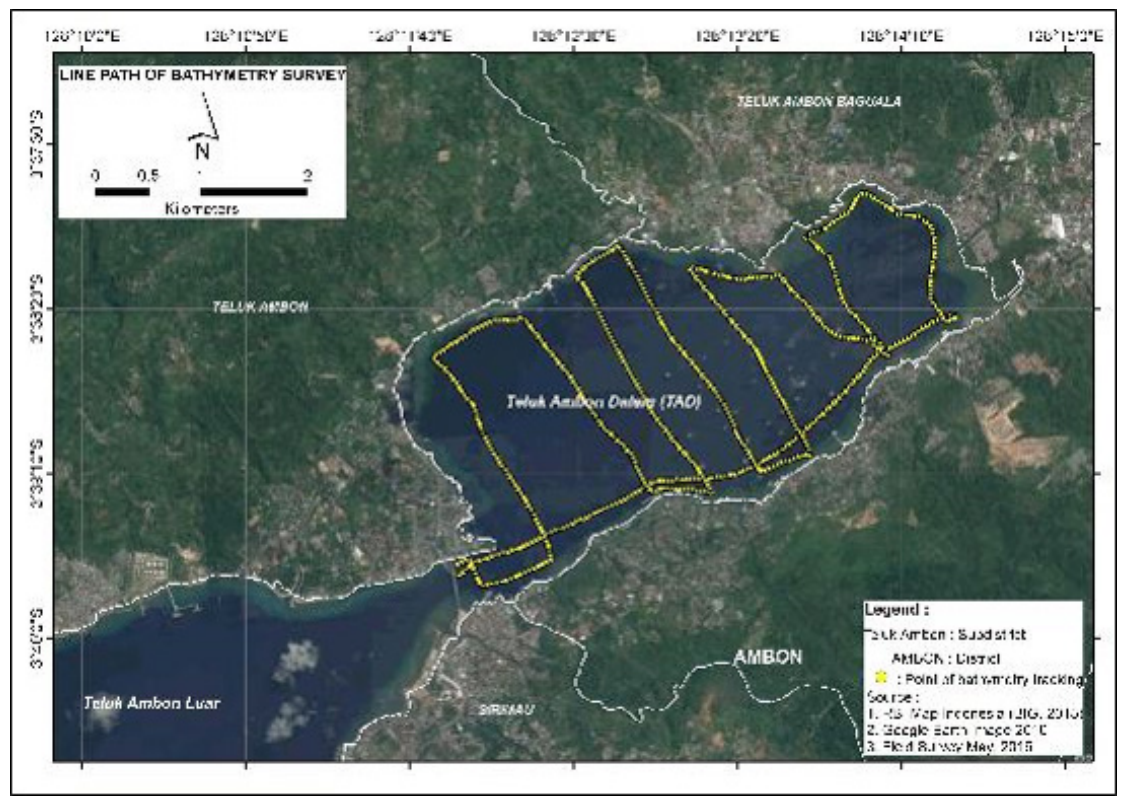

Figure 2. Line path of bathymetry survey.

sedimentation issue strongly threats Ambon Bay. Bathymetry analysis model approach is the best way to observe total sediment distributed by hydrooceanography factors. This study aimed to determine the distribution of sediment volume within Ambon Bay based on the interpretation of bed thickness changes.

\section{METHODOLOGY}

\section{Bathymetry analysis}

This research was conducted on May 2016 in TAD area, positioned between $3^{\circ} 40^{\prime \prime} 11^{\prime} S-3^{\circ} 38^{\prime \prime} 45^{\prime} \mathrm{S}$ and $128^{\circ} 11^{\prime \prime} 34^{\prime}$ E - 128 14 "30' E (Figure 1). Primary data were collected by measuring bathymetry, current, and tide, and secondary were obtained from PUSHIDROSAL (Indonesian Navy Department of Hydro-Oceanography) bathymetry maps of Ambon, year 2014 and scale of 1:25.000 (maps number: 398).

Bathymetry of TAD was surveyed by using transducer, where the depth of certain position was connected to GPS that recorded all the position data accurately. The acoustic method was implemented for this survey by deploying Echosounder Echo track CVM Teledyne Odom Hydrographic Single Beam that transmits a certain frequency to the seabed to obtain real-time depth. Once all the planned routes - its position and depth - were gathered, data can be processed by modeling seabed in $2 \mathrm{D}$ and $3 \mathrm{D}$ profiles. Interval of bathymetry routes are about $500 \mathrm{~m}$ (Figure 2).

Tidal data for 15 days were recorded by HOBOware in the certain location. This kind of data was processed using admiralty method (Rahmawan et al., 2016) to calculate mean sea level (MSL) to classify tidal type in the study area. Bathymetry result must be corrected using tidal elevation during the survey and transducer depth. The real depth value defined as a subtraction between transducer corrected depth and a corresponding sea level position reduction value at the time of measurement (Holman et al., 2013).

HOBOware was deployed for 15-days in Wayame waters, through admiralty analysis we obtained several principal tidal constituents (M2, S2, K2, N2, K1, O1, P1, M4 and MS4) that are necessary to calculate MSL (Mean Sea Level) and CD (chart datum) values. CD is the lowest elevation written on map and a reference plane for a mapping process that is very affected by the Zo (Khasanah and Heliani, 2014). Based on The International Hydrographic Organization (IHO) and PUSHIDROSAL, Zo can be determined by the following formula (Fairley et al., 2013):

$$
Z o=\sum_{i=1}^{n} A i
$$

Bathymetry measurement result must be corrected by the tidal condition and the depth of transducer. The real depth value is defined as a subtraction of transducer corrected depth and related reduction value of the sea level position during the time of measurement (Holman et al., 2013):

$$
D=D t-r t
$$

where,
D : The real depth values
Dt: Transducer corrected depth 
rt : Sea level position reduction value at the time of measurement $(t)$ and $r t$ can be calculated by the following formula:

$r t=T W L t-(M S L+Z 0)$

where

$\begin{array}{ll}\text { TWLt } & \text { : Sea level at time } t \\ \text { MSL } & \text { : Mean Sea Level } \\ \text { Zo } & \text { : Surface elevation beneath the } \\ & \text { lowest ebb }\end{array}$

Furthermore, the corrected depth was then adjusted by a variogram to understand trend and correlation of the data. Topography changes analysis was done by comparing volume and depth of two different topographies of the same location but different times. Year 2014's data were used as the baseline where the changes assumed as zero, and vice versa for 2016's data. The sediment volume calculation was completed by the grid method, which is comparing the topography difference of two different volumes. The volumes were divided into several grids forming squared pyramids that connect the two topographies, as explained by the frustum formula ((Ju et al., 2013); Kakisena et al., 2015);

$$
V=\frac{h}{3}\left[A_{1}+A_{2}+\sqrt{A_{1} A_{2}}\right]
$$

where

$\begin{array}{ll}\mathrm{V} & \begin{array}{l}\text { : The volume of square pyramid } \\ \text { Sediment volume }\left(\mathrm{m}^{3}\right)\end{array} \\ \mathrm{A} 1 & : \text { Area of the upper field }\left(\mathrm{m}^{2}\right) \\ \text { A2 } & : \text { Area of the bottom field }\left(\mathrm{m}^{2}\right) \\ \mathrm{h} & : \text { The height of pyramid }(\mathrm{m})\end{array}$

The seabed topography of year 2014 and 2016 were displayed as 2D contour by implementing Kriging Method that might be functioned as an appropriate interpolator or smoothing tool depends on used parameters (Wang et al., 2015). The graphic was presented by forming long and cross profile (Figure 3 ).

\section{Hydro-Oceanography}

Acoustic Doppler Current Profiler (ADCP) was deployed from 18/05/2016 at 15:00 pm until 20/05/2016 at $12.00 \mathrm{am}$ within the bay with approximate measurements of three days. The ADCP records current data in the form of velocity component of current. While, tidal data sourced from HOBO measurement were used as input for tide forecasting. In another case, the currents and tides data are used in the validation the hydrodynamic modeling result (Wisha et al., 2016). To evaluate the model result, it must be compared with field measurement of tidal and current data ( Jin \& Ji, 2004), applying Root Mean Square Error (RMSE) formula as follows:

$$
R M S E=\sqrt{\frac{1}{N} \sum(x i-y i)^{2}}
$$

where,

$$
\begin{aligned}
& \mathrm{N}=\text { Total data } \\
& \mathrm{xi}=\text { Model result } \\
& \text { yi }=\text { Field measurement data }
\end{aligned}
$$

Flow model flexible mesh was employed to determine the distribution pattern of sediment, transported by the water mass dynamics. Tidal currents simulation was simulated for 15 days, the data will be displayed during four extreme tidal conditions (Spring high tidal condition, spring low tidal condition, neap

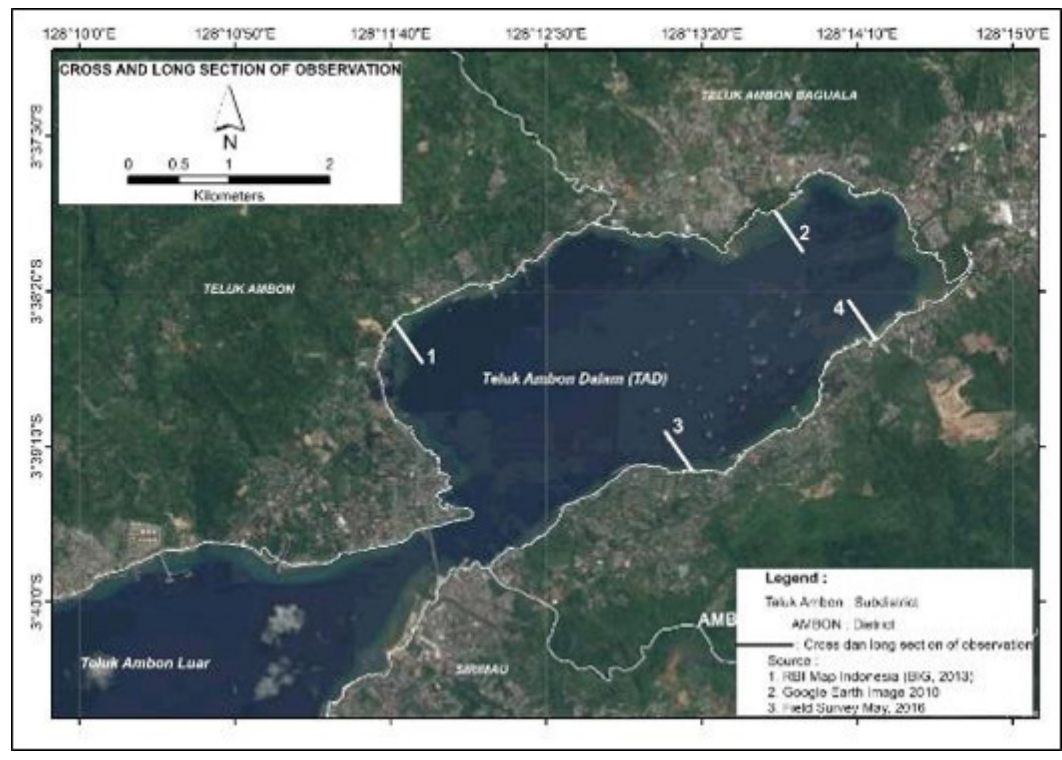

Figure 3. Cross sections of observation area. 
Table 1.

Set-up for hydrodynamic model

\begin{tabular}{|c|c|}
\hline Parameter & Implemented in simulation \\
\hline Simulation time & $\begin{array}{l}\text { Number of time step }=100 \\
\text { Time step interval }=30 \text { second } \\
\text { Start and stop simulation date }=18 / 05 / 201624.00-3 / 06 / 201600.50\end{array}$ \\
\hline Mesh boundary & $\begin{array}{l}\text { Bathymetry = PUSHIDROSAL bathymetry map digitation combined with field } \\
\text { measurement } 2016 \\
\text { Coastline = Google Earth Image digitation }\end{array}$ \\
\hline Flood and Dry & $\begin{array}{l}\text { Drying depth }=0.005 \mathrm{~m} \\
\text { Flooding depth }=0.05 \mathrm{~m} \\
\text { Wetting depth }=0.1 \mathrm{~m}\end{array}$ \\
\hline Boundary condition & $\begin{array}{l}\text { Tide forecasting with coordinates: } \\
\text { 1. Longitude: } 128.027 \text {; Latitude: }-3.774 \\
\text { 2. Longitude: } 128.051 \text {; Latitude: }-3.786 \\
\text { 3. Longitude: } 128.079 \text {; Latitude: }-3.789\end{array}$ \\
\hline
\end{tabular}

high tidal condition, and neap low tidal condition). Flow model results depict the data in the form of twodimensional (Warren \& Bach, 1992; Mehdiabadi et al., 2015). The input of model developed employed bathymetry data from Hydrography and Oceanography Center, Indonesian Navy (PUSHIDROSAL) combined with Bathymetry measurement result and digital coastline Google Eye imagery 2016. The surface elevation was obtained by employing ERGtide in the form of time series data. Set-up of hydrodynamic model is shown in Table 1. Wind data were not used because Ambon inner bay is a semi-enclosed and narrowed water area where the wind influence is minimal. Thus, we simulated only for tidal current pattern that is predominant controlling transport mechanism within the bay.

\section{RESULTS AND DISCUSSION}

\section{The Bathymetry changes during $2014-2016$}

As displayed in Figure 3, the depth of TAD in 2014 ranged between 0 - 42 meters (Figure 4a), while in 2016 the water depth slightly changed to 0 - 44 meters (Figure 4b). From the comparison between this twoyear bathymetry data, the water's depth changes from the shoreline up to the offshore.

The depth of waters contour in 2016 were less dense than in 2014, indicating that the TAD's seabed becomes more ramp than in 2014 that can be assumed as the impact of the high rate sedimentation. Its semienclosed position and the calm current speed make TAD waters more turbid compared with TAL (outer bay of Ambon). Moreover, the topography of Ambon that dominated by elongated hilly and mountainous area made it easy for compacted sediment to be transported into Ambon Bay through flood and erosion. These conditions are pernicious to the coastal condition, several problems such as coastline change, water degradation, as well as pollution will be threatening.

According to Gemilang et al. (2017) defined Total Suspended Solid (TSS) in TAD categorized above the standard established by the Ministry of Environment, which is more than $20 \mathrm{mg} / \mathrm{l}$. It is not suitable for seagrass and coral growth. According to Wisha \& Heriati (2016) increase of sedimentation brings adverse effects to biotic environment changes, such as coral, seagrass and seaweed covered by sediment. So that sedimentation process affecting turbidity, changes
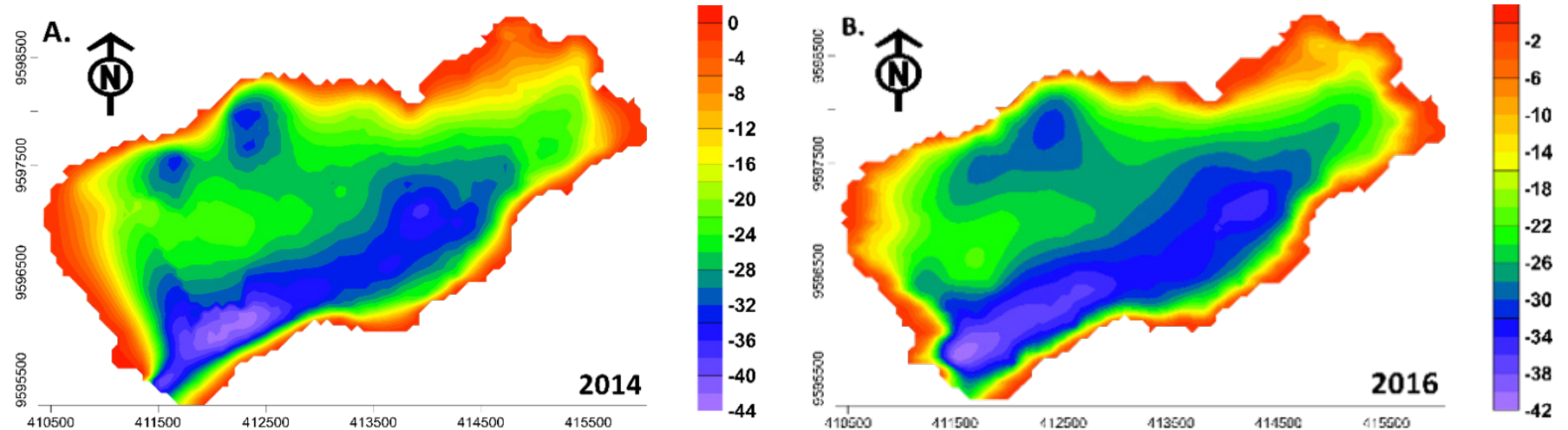

Figure 4. Bathymetry profile of Inner Ambon Bay. 
in coastal morphology and directly disrupts shipping traffic in and out of the harbor (Napitupulu et al., 2015).

\section{Horizontal analysis of seabed profile}

To analyze horizontal seabed profile, $350 \mathrm{~m}$ cross section profile is possible unfurled from coastline. The blue line (bathymetry profile in 2016) and red line (bathymetry profile in 2014) show the change of the sedimentation thickness along the cross sections, thus the depth changes were obtained as described by profile 1, 2, 3, and 4 (Figure 5).

Profile 1 shows that the shallower area experiences accretion approximately ranged between 1-2 $\mathrm{m}$. While in the deeper area, the sedimentation is observed which it enhances ranged between 1-3 $\mathrm{m}$. These conditions indicate that the longshore current takes place, triggering scour in the shallower area, bringing the scoured materials into the deeper area within the bay. Profile 1 represents the area of Ambon Bay Peninsula that the deformation of current pattern is predominant, inducing sediment movement in the surrounding. The funnel shape of the bay mouth triggers the enhancement of current speed, that directly affects the higher local transport (Oostdam \& Jordan, 1972).

Cross section of profile 2 shows that the bed thickness is slightly changing. Sediment augmentation is observed between the depth of $3-10 \mathrm{~m}$ (to be consistent) that the bed thickness change ranged between 1-2 $\mathrm{m}$, while that condition is also occurred in the depth of $28 \mathrm{~m}$ in the distance of $300 \mathrm{~m}$ from the coastline. This cross section represents the area of city center where the anthropogenic factors are predominant triggering the higher sedimentation within the bay.

Equal bed thickness shown in profile 3 is observed in the depth of 0-5 $\mathrm{m}$ along the distance of $100 \mathrm{~m}$ from the coastline. Sedimentation is identified in the depth of 5-10 m which the bed thickness change ranged from 1-4 $\mathrm{m}$. As a result, erosion is occurred in the deeper part along the distance between 200-300 $\mathrm{m}$. This cross-section area represents the bay mouth where the water mass rapidly moves in and out the bay due to its convergence shape that induces strong tidal current speeds.

The opposite condition is identified in the cross-section profile 4, showing the tremendous sedimentation occurred in the depth of $0-30 \mathrm{~m}$ along the distance between 0-300 $\mathrm{m}$ from the coastline. While, the sedimentation is only identified in the depth of around $20 \mathrm{~m}$ which the bed thickness enhances approximately $5 \mathrm{~m}$. This section represents the area of the weakest transport mechanism due to the weak current profile. This area is the most significant where the downtown is located. The sediment supply from the mainland through rivers and estuaries play a big role in enhancing the sedimentation in this area.

The topographic condition changes at a certain location along 0 to $350 \mathrm{~m}$ toward the sea due to sedimentation, the blue line is a description of the topography in 2016, while the red line is the depth contour line of the 2014 Hydrography and Oceanography Center, Indonesian Navy (PUSHIDROSAL) bathymetry data.

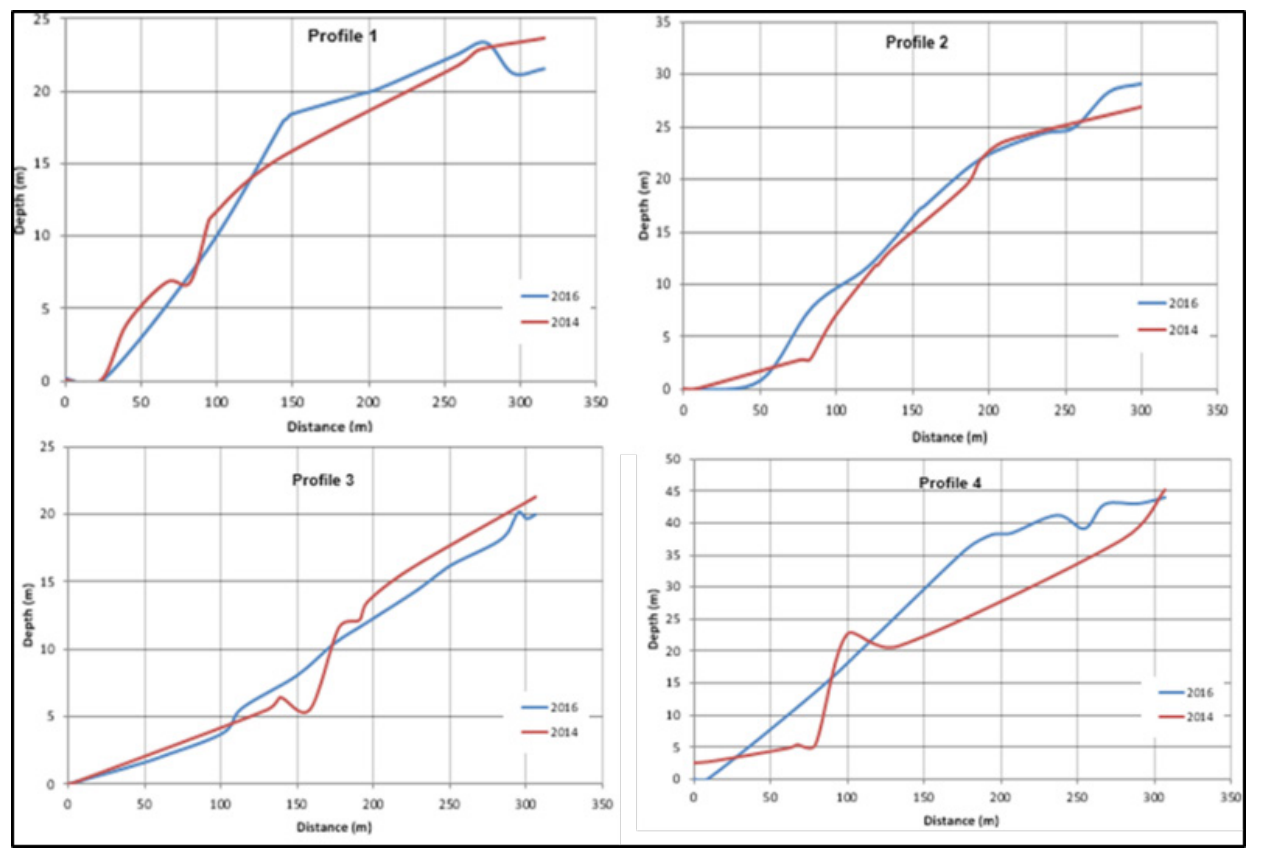

Figure 5. Cross section sliced of overlaid bathymetry data. Red line: 2014 and blue line:2016. 
The reduced water depth occurred in the $25-125$ $\mathrm{m}$ from the shoreline, where sediment deposit of 0.1 $\mathrm{m}$ to $1.4 \mathrm{~m}$ was observed. Meanwhile, the sediment augmentation changes the seabed morphology in the form of sediment augmentation and subtraction area. The average changes in the bathymetry profile during 2014-2016 is displayed in Table 2. However, the sediment deposition is one of factors influencing mangrove ecosystem damage (Alongi, 2008). Moreover, the high deposition rate may endanger mangrove forest in TAD which is still classify into primary forest.

\section{Sediment distribution coverage in TAD}

Based on the difference of waters depth between the year 2014 and 2016, we calculated the deposited volume of sediment by implementing frustum formula as mentioned before. The illustration result of sediment distribution is shown in Figure 6 . The total volume of sediment augmentation reached 21,691,198 $\mathrm{m}^{3}$ covers about $798.4 \mathrm{Ha}$, while the sediment subtraction volume reached 2,982,946 $\mathrm{m}^{3}$ are distributed in an area about $224.2 \mathrm{Ha}$. According to Bakke et al. (2013) quantifying sedimentation impacts to threatened fish stocks, while indicating possible avenues for geomorphic

Table 1. Set-up for hydrodynamic model

\begin{tabular}{llll}
\hline Statistics & $\mathbf{2 0 1 4}$ & $\mathbf{2 0 1 6}$ & Deviation $(\mathbf{m})$ \\
\hline Min & -39.63 & -39.86 & \\
Max & -1.15 & -1.89 & \\
Average & -20.72 & -23.63 & 2.91 \\
\hline
\end{tabular}

stratification of impact severity.

Average augmentation in TAD is about $1.83 \mathrm{~m} /$ year during 2014-2016 that is slightly different from the previous study by Indonesian Institute of Science (LIPI) (2008) that found the augmentation rate about $3.0 \mathrm{~cm} /$ year during 1982-2008. According to Kakisina et al. (2015), the problems of decreasing quality of coastal environmental as a result of unplanned and uncontrolled development, while, according to Tuahatu et al. (2016) the existence of sedimentation in mangrove ecosystems is observed in Passo Village, Inner Ambon Bay which the bathymetry profile was degraded about $0.61 \mathrm{~m} /$ year. Figure 6 depicts the area experienced sedimentation which extraordinarily reaches $798.4 \mathrm{Ha}$.

According to Kakisina et al. (2016) landuse transformation of this area in 1972, 1987, 2001, and 2014 were about 856.260 ha, 1,812.104 ha, 4,141.096 ha and 4,505.012 ha, respectively. The great changes are caused by the intensive development of settlement, office, industrial, and commercial areas, which the biggest change was occurred in Sirimau District and Baguala Bay.

The sedimentation source cannot be separated from the activities along the Galala River's estuary located around Ambang Galala-Rumahtiga and in between TAD and TAL waters. The addition of developed area and the land clearing in the hilly area also impact the tremendous sediment accumulation.

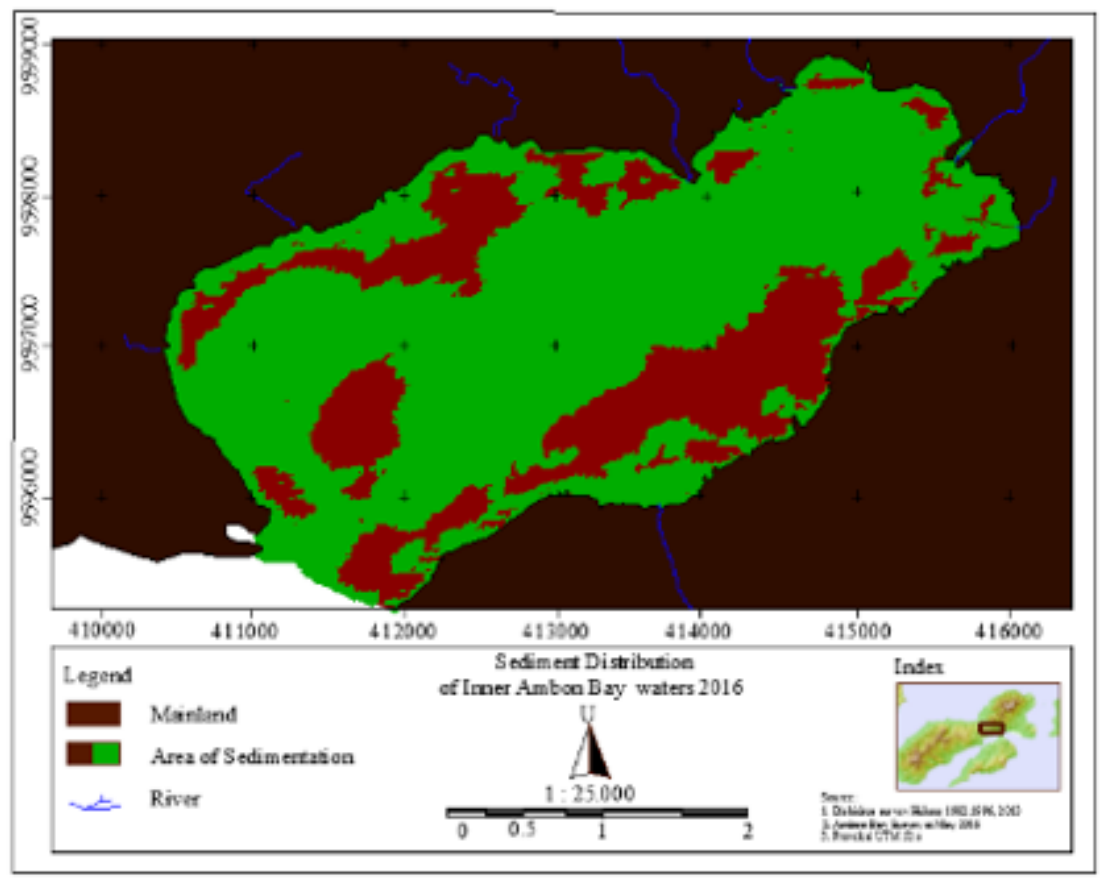

Figure 6. The latest condition of Sediment distribution of Inner Ambon Bay. 
The sedimentary enhancement in Galala River and Ambang Galala-Rumahtiga is very alarming in the last few years. The changes happened in the upstream landuse that was utilized as a new settlement area since 1998. Based on overlaid bathymetry map and shoreline changes of year 1980 - 2005, the seabed and coastal morphology of Galala-Tantui show that the siltations and shoreline changes mostly occurred in the Galala River mouth to the Northeast. The slow current velocity indicates the heterogeneity in sediment distribution in the river mouth of TAD area, which caused sediment precipitation around the river mouth (Leuwol \& Sunarto, 2006).

\section{Tidal current pattern of TAD}

The validation was done by comparing field measurement data and model result (Lazure et al., 2009; Wisha et al., 2017). In this study, surface elevation data are used to verify the model built. The comparison of surface elevations between model (orange line) and observation data (blue line) (Figure 7) shows the similarity of tidal phases. The RMSE value obtained is $3.78 \%$. Based on the tidal analysis, the tidal type of TAD is mixed tide prevailing semi-diurnal. It was also explained by Pattipeilohy (2014).

TAD's tidal profile has a big role in inducing transport mechanism within the bay (Noya et al., 2016) which is almost occurred twice elevation changes with the same phases, resulting in the transportation of sediment with a high volume. Semi-enclosed area of TAD triggers the deposition of sediment. It is clear why the sedimentary rate is higher in TAD. Tidal current may play an important role in the transportation and deposition of sediment (Wisha et al., 2017a).

Tidal current speed during spring high tidal condition ranged from $0-1.2 \mathrm{~m} / \mathrm{s}$, while during neap tidal condition, the current speed increased ranged from $0-1.12 \mathrm{~m} / \mathrm{s}$. The current pattern both high spring and high neap tidal conditions predominantly moves toward northeast, it propagates as longshore current which induces erosion and sedimentation within the bay (Figure 8 ). The water mass flows from the higher elevation in the open sea to the lower elevation within the bay during high tidal condition. According to Wisha \& Heriati (2016) current profile within semi-enclosed bay is mainly influenced by tidal fluctuations which control the distribution of sediment in and out the bay.

At the low tidal condition, the current speed ranged from $0-0.42 \mathrm{~m} / \mathrm{s}$ and $0-0.22 \mathrm{~m} / \mathrm{s}$ for spring and neap respectively. The water mass flows toward the bay mouth where the current speed enhances dramatically due to the convergence path (roughly funnel-shaped) of bay mouth. Transport mechanism during low tidal conditions is not too significant, this situation enhances the possibility of sediment deposition within the bay. According to Nowacki \& Ogston (2013) interaction between morphology of the funnel channel and tidal fluctuations produces well-defined velocity pulses (water and suspended-sediment transports) in which the transport is weaker during ebb tide (low tidal condition).

The current profile is stronger during spring tidal condition due to the higher influence of astronomical forces. This condition depicts that the sediment transport may occur highly. The tidal type of TAD has a big role in evoking turbulence and deposition of sediment within the bay. It is clear why in TAD seems more turbid, indicating the high turbulence occurred within the bay due to hydro-oceanography factors. According to Wisha et al. (2017b) longshore current mainly controls the erosion and sedimentation processes in the coastal area which induces turbulence beneath its propagation.

The bay mouth that is funnel-shaped semienclosed area is a deep water. The depth ranged from $-26--44$ meters (Figure 4). It is obvious that this area has a highest transport due to the strong current speed (ranging from $0.8-1.2 \mathrm{~m} / \mathrm{s}$ ). In the other area within the bay that has a lower circulation (TAD peninsula/ Waiheru, Passo, and Lateri), the sediment tends to

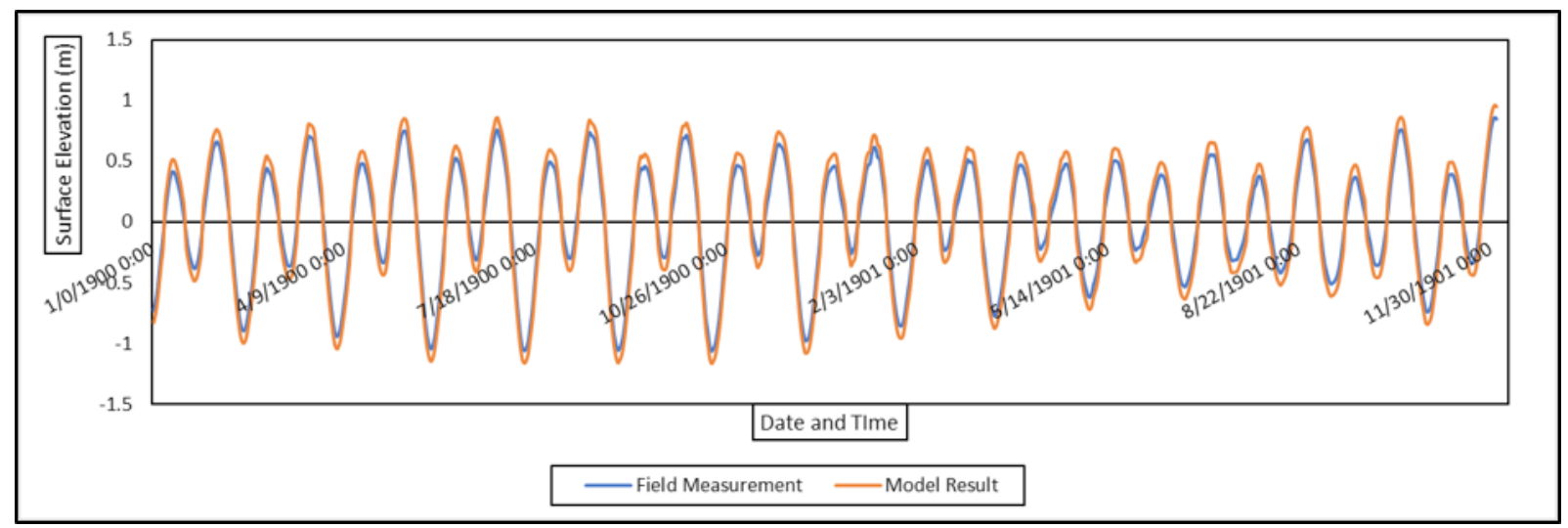

Figure 7. Model validation using surface elevation data. 
be settled. Those results are supported by previous research Noya et al. (2016), defined that the maximum concentration of the suspended sediment occurs at the head of the bay (around Waiheru, Passo, and Lateri). Supported by river discharge, sedimentation in TAD is undoubtedly avoided. According to Pattipeilohy (2014) the sedimentation issues in TAD is also triggered by forest utilization change and flood-erosion.

\section{CONCLUSION}

The depth of waters contour in 2016 were less dense than in 2014. The topography of Ambon Bay that is predominated by elongated hilly and mountainous area makes the compact sediment will be easily transported to Ambon Bay through flood and erosion. The topographic condition changes at a certain location along 0 to 350 meters toward the sea due to the sedimentation. The sediment augmentation changes the seabed morphology in form of sedimentation and subtraction area.

Tidal current profile has a significant role in controlling erosion and sedimentation within the bay. The area of highly turbid indicates that the sedimentation frequently occurs (around Waiheru,
Passo, and Lateri). The bay mouth that is funnelshaped semi-enclosed area triggers a high transport mechanism on its surrounding. Interaction between morphology of the funnel channel and tidal fluctuations produces well-defined velocity pulses (water and suspended-sediment transports).

Due to the limited data collected, we encourage the next research can totally define the sediment transport mechanism in TAD related with the sedimentation, coastline change, as well as morphological change. This study can be useful for local government to maintain the sedimentation level in TAD by applying a frequent dredging because TAD has become the area of significance and now it is threatened by sedimentation issues.

\section{ACKOWLEDGEMENTS}

Acknowledgment and gratitude are given to Research Institute for Coastal Resources and Vulnerability on DIPA 2016 research budget in Ambon Bay, to Gunardi Kusumah, and all those who have assisted in the completion of this scientific paper.
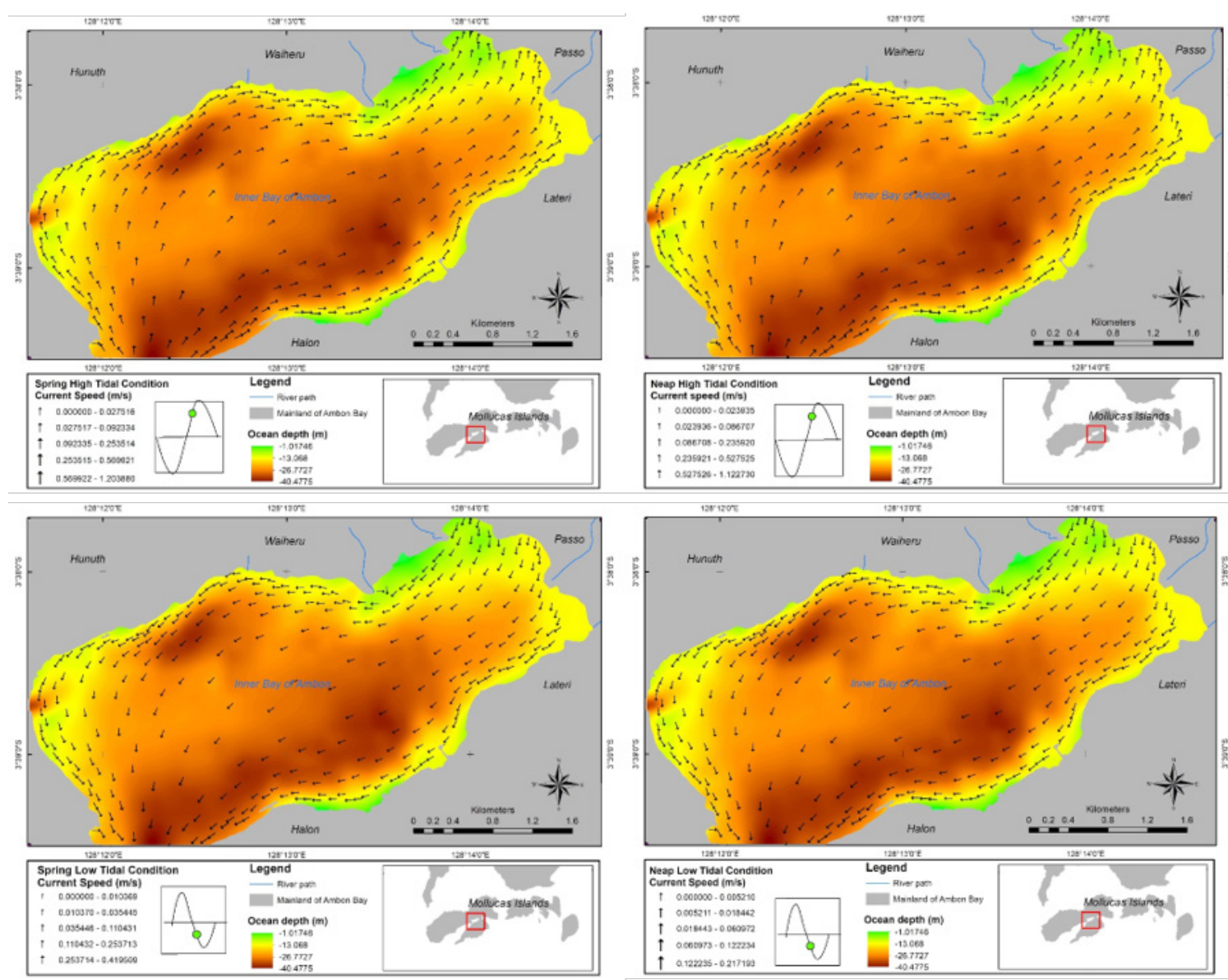

Figure 8. Tidal current simulation during spring and neap tidal conditions. 


\section{REFFERENCE}

Alongi, D. M. (2008). Mangrove forests: resilience, protection from tsunamis, and responses to global climate change. Estuarine, Coastal and Shelf Science, 76(1), 1-13.

Bakke, T., Klungsøyr, J., \& Sanni, S. (2013). Environmental impacts of produced water and drilling waste discharges from the Norwegian offshore petroleum industry. Marine environmental research, 92, 154-169. https://doi.org/10.1016/j. marenvres.2013.09.012.

Bappeda Kota Ambon, (2009). Master Plan Ambon Water Front City.

Fairley, I., Evans, P., Wooldridge, C., Willis, M., \& Masters, I. (2013). Evaluation of tidal stream resource in a potential array area via direct measurements. Renewable Energy, 57, 70-78. https://doi.org/10.1016/j.renene.2013.01.024.

Gemilang, W. A., Rahmawan, G. A., \& Wisha, U. J. (2017). Kualitas Perairan Teluk Ambon Dalam Berdasarkan Parameter Fisika dan Kimia pada Musim Peralihan I. EnviroScienteae, 13(1), 7990. http://dx.doi.org/10.20527/es.v13i1.3518.

Hamzah, M. S. \& Wenno, L. (1987). Sirkulasi arus di teluk ambon. Balai Penelitian dan Pengembangan Sumberdaya Laut, Teluk Ambon; Biologi, Perikanan, Oseanografi dan Geologi, 91$101 \mathrm{pp}$.

Holman, R., Plant, N., \& Holland, T. (2013). cBathy: A robust algorithm for estimating nearshore bathymetry. Journal of geophysical research: Oceans, 118(5), 2595-2609. https://doi. org/10.1002/jgrc.20199.

Irawan, A., \& Nganro, N. R. (2016). Distribution of Seagrasses in Inner Ambon Bay. Jurnal Ilmu dan Teknologi Kelautan Tropis, 8(1). 99-114. http:// dx.doi.org/10.29244/jitkt.v8i1.12499.

Jin, K. R., \& Ji, Z. G. (2004). Case study: modeling of sediment transport and wind-wave impact in Lake Okeechobee. Journal of hydraulic engineering. 130(11): 1055-1067. https://doi.org/10.1061/ (ASCE)0733-9429(2004)130:11(1055).

Ju, L., Wen, A. B., Long, Y., Yan, D. C., \& Guo, J. (2013). Using $137 \mathrm{Cs}$ tracing methods to estimate soil redistribution rates and to construct a sediment budget for a small agricultural catchment in the three gorges reservoir region, China. Journal of Mountain Science, 10(3), 428-436. https://doi. org/10.1007/s11629-013-2585-9.

Kakisina, T. J., Anggoro, S., \& Hartoko, A. (2015). Analysis of the Impact of Land Use on the Degradation of Coastal Areas at Ambon Bay-mollucas Province Indonesia. Procedia Environmental Sciences, 23, 266-273. https://doi. org/10.1016/j.proenv.2015.01.040.

Kakisina, T. J., Anggoro, S., \& Hartoko, A. (2016). NEMOS (Nearshore Modelling of Shoreline Change) Model for Abrasion Mitigation at the Northern Coast of Ambon Bay. Aquatic Procedia, 7, 242-246. https://doi.org/10.1016/j. aqpro.2016.07.034.

Khasanah, U., \& Heliani, L. S. (2014). Perhitungan Nilai Chart Datum Stasiun Pasang Surut Jepara Berdasarkan Periode Pergerakan Bulan, Bumi, Dan Matahari Menggunakan Data Pasut Tahun 1994 Sd 2013. Jurnal Geospasial Indonesia, ISSN, 2222-2863.

Leuwol, F. S., \& Sunarto, M. S. (2006). Pengaruh sedimen Sungai Galala terhadap perubahan garis pantai di perairan Teluk Ambon (Doctoral dissertation, Universitas Gadjah Mada).

Mehdiabadi, F. E., Mehdizabeh, M. M., \& Rahbani, M. (2015). Simulating Wind Driven Waves in the Strait of Hormuz using MIKE 21. IImu Kelautan. 20(1): 6-13. https://doi.org/10.14710/ik.ijms.20.1.1-8.

Mizushima, K., Matsuoka, K., \& Fukuyo, Y. (2007). Vertical distribution of Pyrodinium bahamense var. compressum (Dinophyceae) cysts in Ambon Bay and Hurun Bay, Indonesia. Plankton and Benthos Research, 2(4), 163-174. https://doi.org/10.3800/ pbr.2.163.

Napitupulu, R. M. F., Sugianto, D. N., \& Hariyadi, H. (2015). Pemetaan Batimetri Sebagai Pertimbangan Penentuan Alur Pelayaran Di Perairan Pulau Panjang, Jepara. Journal of Oceanography, 4(1), 223-232.

Nowacki, D. J., \& Ogston, A. S. (2013). Water and sediment transport of channel-flat systems in a mesotidal mudflat: Willapa Bay, Washington. Continental Shelf Research, 60, S111-S124. https://doi.org/10.1016/j.csr.2012.07.019.

Noya, Y. A., Purba, M., Koropitan, A. F., \& Prartono, T. (2017). Cohesive Sediment Transport Modeling on Inner Ambon Bay. Jurnal IImu dan Teknologi Kelautan Tropis, 8(2), 671-687. https://doi. org/10.28930/jitkt.v8i2.15834. 
Oostdam, B. L., \& Jordan, R. R. (1972). Suspended sediment transport in Delaware Bay. In Environmental Framework of Coastal Plain Estuaries. pp. 143-149. https://doi.org/10.1130/ mem133-p143.

Pattipeilohy, M. (2014). Fenomena Pendangkalan Zona Pasang Surut Hutan Mangrove Teluk dalam Ambon serta Upaya Pengembangan Ekowisata. Jurnal Pena Sains, 1(2), 56-63.

Pownall, J.M., Hall, R., \& Watkinson, I.M., (2013). Extreme extension across Seram and Ambon, eastern Indonesia: evidence for Banda slab rollback. Solid Earth, 4(2): 277. https://doi. org/10.5194/sed-5-525-2013.

Purwoko A. (2009). Function Analysis and Land Change in Coastal Area Using Satellite Imagery Based Geographic Information System (A Case Study in the Area Wild life Coral Ivory and Langkat Northeast). Journal of Planning and Regional Development (4)3.

Rahmawan, G. A., Wisha, U. J., \& Husrin, S. (2017). Analisis Batimetri Dan Pasang Surut Di Muara Sungai Kampar: Pembangkit Penjalaran Gelombang Pasang Surut Undular Bore (BONO). GEOMATIKA, 22(2), 57-64. http://dx.doi. org/10.24895/JIG.2016.22-2.573.

Sihasale, D. A. (2013). Keanekaragaman Hayati di Kawasan Pantai Kota Ambon dan Konsekuensi untuk Pengembangan Pariwisata Pesisir. Journal of Indonesian Tourism and Development Studies, 1(1), 20-27.

Souisa, M., Hendrajaya, L., \& Handayani, G. (2016). Landslide hazard and risk assessment for Ambon city using landslide inventory and geographic information system. In Journal of Physics: Conference Series. IOP Publishing. 739(1), https://doi.org/10.1088/1742-6596/739/1/012078.

Sutarna, I. N. (1989). Kondisi karang di teluk Ambon bagian dalam Teluk Ambon. Biologi, perikanan, oseanografi dan geologi, pp.13-22.

Suyadi, S., (2017). Satu Dekade Kondisi Hutan Mangrove di Teluk Ambon, Maluku (A Decade of Mangrove Forest Condition in Ambon Bay, Maluku). Jurnal Biologi Indonesia, 8(1).

Thomson, R.E. and Emery, W.J., (2014). Data analysis methods in physical oceanography. Newnes.

Tuahatu, J.W., Hulopy, M. and Louhenapessy, D.G., (2016). Community structure of seagrass in Waai and Lateri waters, Ambon Island, Indonesia. Aquaculture, Aquarium, Conservation \& Legislation-International Journal of the Bioflux Society (AACL Bioflux), 9(6).

Tuhumury, N. C., Sahetapy, J.M.F. and Louhanapessy, D.G., (2007). Permasalahan sedimentasi dan pengelolaannya di pesisir Lateri Kota Ambon. J. Penelitian IImu-ilmu Perikanan dan Kelautan, 2(1), pp.17-22.

Wang, T., Belle, I., \& Hassler, U. (2015). Modelling of Singapore's topographic transformation based on DEMs. Geomorphology, 231, 367-375. https://doi. org/10.1016/j.geomorph.2014.12.027.

Warren, I. R., \& Bach, H. (1992). MIKE 21: a modelling system for estuaries, coastal waters and seas. Environmental Software, 7(4), 229-240. https:// doi.org/10.1016/0266-9838(92)90006-P.

Wisha U. J., S. Husrin, \& G. S. Prasetyo. (2016). Hydrodynamics of Bontang Seawaters: Its Effects on the Distribution of Water Quality Parameters. IImu Kelautan. 21(3): 123-134. https://doi. org/10.14710/ik.ijms.21.3.123-134.

Wisha, U. J., Al Tanto, T., Pranowo, W. S., \& Husrin, S. (2017a). Current movement in Benoa Bay water, Bali, Indonesia: Pattern of tidal current changes simulated for the condition before, during, and after reclamation. Regional Studies in Marine Science. 18: 177-187. https://doi.org/10.1016/j. rsma.2017.10.006.

Wisha, U. J., Ondara, K., \& Kusumah, G. (2017b). An Overview of Surface Water Quality Influenced by Suspended Solid Content in the Sayung Waters, Demak, Indonesia. Jurnal Segara, 13(2): 107-117. http://dx.doi.org/10.15578/segara.v13i2.6446. g5420.

Wisha, U.J. and Heriati, A., (2016). Bathymetry and Hydrodynamics in Pare Bay Waters During Transitional Seasons (September-October). Omni-Akuatika, 12(2). https://doi.org/10.20884/1. oa.2016.12.2.98.

Wu, X., Shen, Z., Liu, R. and Ding, X. (2008). Land use/cover dynamics in response to changes in environmental and socio-political forces in the upper reaches of Yangtze River, China. Sensors, 8(12), pp.8104-8122. http://dx.doi.org/10.3390/ s8128104. 
